\title{
A Study on the Maritime Transport Network Design under Different Charter Rates: The Case of LNG Transport between Qatar \& Turkey
}

\author{
Salem Y. Lakhal \\ Green Supply Chain Group, \\ Université de Moncton, University Campus, Moncton, NB, E1A 3E9, Canada \\ Email: salem.lakhal@umoncton.ca
}

\begin{abstract}
Many indicators show that the total global LNG demand has risen by an estimated $7.6 \%$ per year since 2000 . Over the same period, the growth is almost three times faster compared to the natural gas growth estimated at $2.7 \%$ per year. As a consequence, the number of the LNG tankers trip from and to the production fields and the consumptions area is growing. The challenge is to design a cost efficient maritime route for an LNG tankers. This article investigates: $(i)$ how, the frequent fluctuation of the Bunker price, the Suez Canal tolls, terrorism activities etc. might affect decision of the LNG Tankers maritime routes and (ii) suggest a framework to help the redesign of a maritime transport routes for LNG vessels. To illustrate this framework developed, the case of the LNG transport between Qatar and Turkey is analysed with an extension made to a maritime route from Asia to Europe. The paper's contribution to the literature is the development of a routing scheme design achieving LNG handling cost savings from Asia to Europe.
\end{abstract}

Keywords: $L N G$, maritime transport, transport network, Suez Canal, cap of good hope

\section{INTRODUCTION}

The demand for natural gas (Figure 1), fueled by economic growth, continues to increase at the global level (Bernstein, Tuladhar et al. 2016). Many indicators show that the total global LNG demand has risen by an estimated $7.6 \%$ per year since 2000. Over the same period, the growth is almost three times faster compared to the natural gas growth estimated at 2.7\% per year (EY 2017). Since the end of 2014, the drop in Bunker price has lead to companies struggling with low charter rates, thus, encouraging the use of LNG tankers. Therefore, in the case of far regions where there are no gas pipelines in operation, LNG tankers will play an important role in supplying natural gas to regions in short supply and with limited or no domestic production. In this situation, the Middle East gas producers could not find a way to supply their natural gas by pipeline to Europe or even Turkey due to a turbulent environment in Iraq and Syria. For this region, the only way to supply their natural gas remains the LNG tankers. In this situation, the Cape of Good Hope maritime route competes with the Canal Suez Route to design the right maritime route. Many parameters should be considered and will be analysed in this paper. Even this problem is economically important, the academic researches related to the LNG transport concerning its economic aspects and the choice of an efficient maritime routes are scarce compared to the researches related to the containers transport.

In this problem there are many parameters (banker price, charter rate, insurance, Suez Canal tolls, etc.) that could influence the decision made. The present market situation is characterised by global LNG shipping markets surpassing the demand combined with a drop of bunker fuel price which has led to a low LNG charter rate (Figure 2).

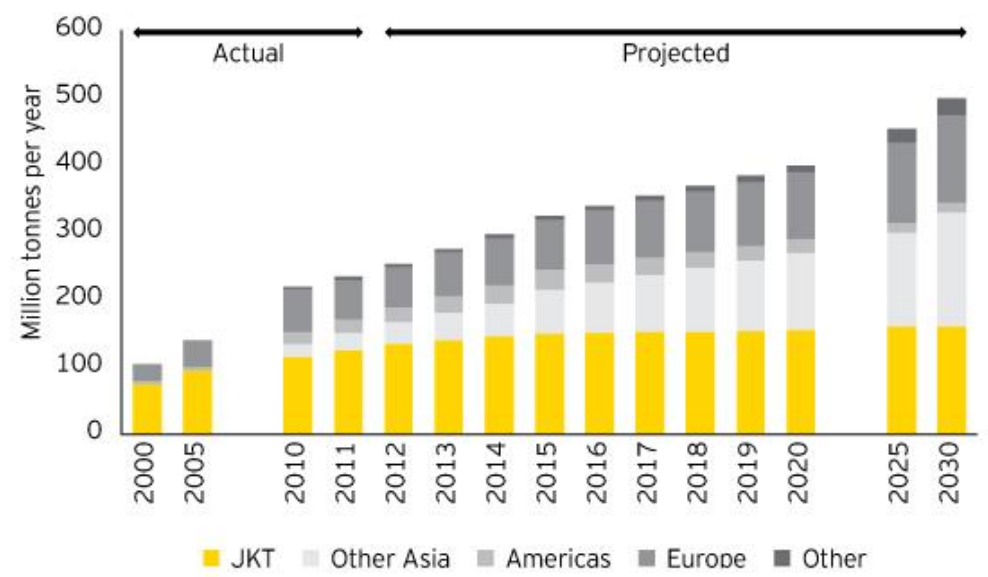

Figure 1 Global LNG demand (Source: EY (2017) assessments of data from multiple sources) 

Operations and Supply Chain Management 11(1) pp. 13 - 25 (C) 2018

The relatively low bunker price encourages vessels to speed up to 22 Knots per hour (according to Drewry's reported by Seanews (2013)). This speed is for containers vessels. For the LNG tanker vessels, a 22 knots per hour seems to be not adopted in practice. Per our investigation in March 2016 through the website http://www.marinetraffic.com/ the average speed of 10 LNG tankers on the service route from Qatar to Japan is 18 Knots. Then, the practice of slow steaming emerged during the financial crisis of 2008-2009 as international trade is no longer the practice due to the low bunker fuel price. This speedup situation privileges the Cap of Good Hope route in detriment of the Suez Canal. The tolls paid to transit via the Suez Canal is an important parameter for the carrier decisions. A challenge for the Suez Canal authority is the adjustment of the toll to remain competitive. As we show in this paper the piracy insurance premium which called also war insurance premium could privileges some routes. In some risky areas the premium could cost USD 30,000 for a three million protection (Roche 2009).

Facing a turbulent situation, where the charter rate is driven by the bunker price, the Suez Canal tolls and the insurances premiums, designing the transport network becomes a daily challenge.

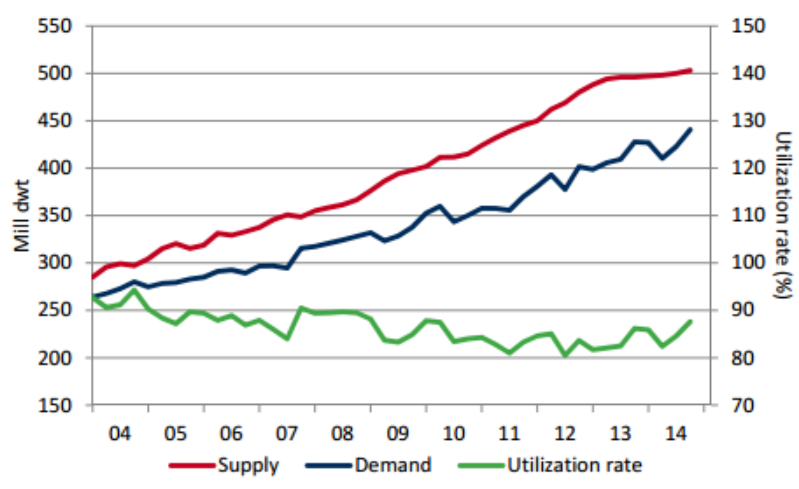

Figure 2 Supply, demand and utilization rate, LNG Tanker Fleet (10,000 dwt) (Source: RS Platou (2015))

This paper attempts to remedy the lack of research in the field of LNG transport analysis. It will analyse the situation where the LNG is transported between Asia and Europe.

The research questions are:

1. With respect to costs, what is the breakeven point equalising the shipper cost for a voyage through the Suez Canal and the Cape of Good Hope for an LNG vessel?

2. How the Suez Canal tolls and the piracy insurance premium and the charter rates impact the choice of decision routes?

The remainder of the paper is organised as follows. Section 2 contains a review of the literature. In Section 3 , the methodology is presented. Section 4 develops the model used to calculate the breakeven point for the shipper. In Section 5 , the model is tested by a using realistic example. A brief discussion of the results is made in Section 6. Finally, in Section 7, the concluding remarks, the implications of the study and a brief outline of possible directions for future research are presented.

\section{LITERATURE REVIEW}

In this section, we focus on the most academic researches pertinent to our study. The maritime routing problem (MRP) and the routes comparison are the best candidates for this review. According to Song and Furman (2013), the MRP is an extremely challenging optimization problem, even with some simplifications and assumptions made in the definition of typical MRP in the literature, it is even more difficult to take advantage of the developed technologies and the practice. Furthermore, despite a growing interest in combined routing and inventory management problems in a maritime setting, no data sets are publicly available, which represents a significant "barrier to entry" for those interested in related research (Papageorgiou, Nemhauser et al. 2014). Some specific problems have been studied like maritime inventory routing for transport multiple non-mixable cement products from producing factories to regional silo stations along the coast of Norway (Christiansen, Fagerholt et al. 2011). It is important to notice that in most cases a mathematical formulation is developed like for the surveillance routing model formulated by Marcel (2006). Some special cases have been studied: the inventory routing problem for a single product produced and consumed at multiple sites (Al-Khayyal and Seung-June 2007, Hewitt, Nemhauser et al. 2013). Other papers have focused on developing algorithms for maritime inventory routing problems (MIRPs) involving routing vessels (Engineer, Furman et al. 2012, Lin and Tsai 2014, Papageorgiou, Keha et al. 2014). In the same vein Chandra, Srivastava et al. (2013) developed an optimization model to address the tactical level maritime planning for logistics ocean transportation of automobiles. Furthermore, Zelasney, Huppert et al. (2011) developed a regression model used to predict the proportion of containerized imports from China shipped on the all-water route directly to US Gulf and East Coast ports based on trade data published by the US Census Bureau. The model employs three predictor variables: oil price, US West Coast labor strife and railroad rates. Another aspect has interested Agra, Christiansen et al. (2015) was oil ship routing and scheduling where it associated with uncertainty in weather conditions and unpredictable waiting times at ports. In their work, they considered both sailing times and port times are to be stochastic parameters. More information related to the main conclusions and methodologies used in papers cited are given in the Table 1. 
Table 1 The most important research on maritime routing problem (MRP)

\begin{tabular}{|c|c|c|c|}
\hline Problem analysed & Author & Conclusion or the results achieved & Methodology \\
\hline $\begin{array}{l}\text { Network for a heterogeneous } \\
\text { fleet of ships engaged in } \\
\text { pickup and delivery of several } \\
\text { liquid bulk products when } \\
\text { serving an archipelago of } \\
\text { islands. }\end{array}$ & $\begin{array}{l}\text { (Al-Khayyal and } \\
\text { Seung-June 2007). }\end{array}$ & $\begin{array}{l}\text { Development of new algorithms that take } \\
\text { advantage of the mathematical model } \\
\text { properties presented. }\end{array}$ & $\begin{array}{l}\text { A mixed-integer nonlinear } \\
\text { program formulation. }\end{array}$ \\
\hline Surveillance routing. & (Marcel 2006) & $\begin{array}{l}\text { Optimal tactics for a single surveillance unit } \\
\text { is a routing problem based on a } \\
\text { mathematical formulation of the surveillance } \\
\text { routing problem is given. }\end{array}$ & $\begin{array}{l}\text { Extension of the travelling } \\
\text { salesman problem. }\end{array}$ \\
\hline $\begin{array}{l}\text { Maritime inventory routing } \\
\text { problems. }\end{array}$ & $\begin{array}{l}\text { (Papageorgiou, } \\
\text { Nemhauser et al. 2014) } \\
\text { (Papageorgiou, Keha } \\
\text { et al. 2014) }\end{array}$ & $\begin{array}{l}\text { A development of a library of publicly } \\
\text { available test problem instances. }\end{array}$ & $\begin{array}{l}\text { Mathematical modelling of a } \\
\text { mixed-integer linear } \\
\text { programming. }\end{array}$ \\
\hline $\begin{array}{l}\text { Ship routing and freight } \\
\text { assignment in the case of } \\
\text { liner carriers. }\end{array}$ & (Lin and Tsai 2014). & $\begin{array}{l}\text { Shanghai, Hong Kong and Singapore are } \\
\text { ports that are ideal for carriers in establishing } \\
\text { daily frequency operations along the Pacific } \\
\text { Rim. }\end{array}$ & $\begin{array}{l}\text { Lagrangian relaxation } \\
\text { technique and local search. }\end{array}$ \\
\hline $\begin{array}{l}\text { Develop an optimization } \\
\text { model to address the tactical } \\
\text { level maritime planning for } \\
\text { logistics ocean transportation } \\
\text { of automobiles. }\end{array}$ & $\begin{array}{l}\text { (Chandra, Srivastava et } \\
\text { al. 2013) }\end{array}$ & $\begin{array}{l}\text { To minimize supply-chain cost and maximize } \\
\text { additional revenue through cargoes using } \\
\text { same fleet of ships, the maritime } \\
\text { transportation planning of internally } \\
\text { managed cargoes should be integrated with } \\
\text { the inventory management at the loading } \\
\text { and discharging ports. }\end{array}$ & $\begin{array}{l}\text { Development of a mixed } \\
\text { integer linear program and } \\
\text { proposition of an iterative } \\
\text { solution technique. }\end{array}$ \\
\hline $\begin{array}{l}\text { Maritime inventory routing } \\
\text { problem, in which the } \\
\text { inventory of a single product, } \\
\text { which is produced and } \\
\text { consumed at multiple sites. }\end{array}$ & $\begin{array}{l}\text { (Hewitt, Nemhauser et } \\
\text { al. 2013) }\end{array}$ & $\begin{array}{l}\text { A reduction of the time needed to find high } \\
\text { quality solutions and presentation } \\
\text { computational evidence of their efficacy. }\end{array}$ & Integer programming. \\
\hline $\begin{array}{l}\text { Complex maritime inventory- } \\
\text { routing problem for an oil } \\
\text { company. }\end{array}$ & $\begin{array}{l}\text { (Engineer, Furman et } \\
\text { al. 2012). }\end{array}$ & $\begin{array}{l}\text { Algorithm is developed for a complex } \\
\text { maritime inventory-routing problem with } \\
\text { varying storage capacities and } \\
\text { production/consumption rates at facilities. }\end{array}$ & $\begin{array}{l}\text { Dynamic program that } \\
\text { exploits certain "external" } \\
\text { characteristics of the pricing } \\
\text { problem. }\end{array}$ \\
\hline $\begin{array}{l}\text { Investigation of the role oil } \\
\text { prices, US West Coast labor } \\
\text { strife and railroad rates on the } \\
\text { cargo shift. }\end{array}$ & $\begin{array}{l}\text { (Zelasney, Huppert et } \\
\text { al. 2011) }\end{array}$ & $\begin{array}{l}\text { The model suggests oil price is positively } \\
\text { correlated with the proportion of } \\
\text { containerized imports from China shipped to } \\
\text { USG\&ECP and that oil price has a greater } \\
\text { influence on the proportion of low value } \\
\text { goods than high value goods shipped on the } \\
\text { all-water route. }\end{array}$ & Regression model. \\
\hline
\end{tabular}

After studying this different paper it seems that the complexity of the maritime routing problem MRP and the lack of public data have not help to give the MRP a great attention in the literature as pointed out also in the reviews of Hennig et al. (2011), Christiansen et al. (2007), Christiansen et al. (2004). Christiansen et al. (2004) presented a review for almost 60 references on the subject published during the decade preceding 2004, this review is updated in 2011 by Hennig et al. (2011) and it appears that this problem treats the assignment of sequences of ports to be visited by the ships. Furthermore, most of the published ship routing and scheduling problems are treated from the carrier side. The general objective of a classical industrial ship scheduling problem is to minimize the sum of the costs for all the ships in the fleet while ensuring that all cargoes are lifted from their loading port to their port of discharge.
These scheduling problems are based on complicated mathematical models greedy in data, hard to implement and difficult to be used for a daily decisions.

On the other hand, concerning the routes comparison, the academic literature appears to be scarce (Schøyen and Bråthen 2011, Wilmsmeier and Notteboom 2011, Gold 2014). Furthermore, the few researchers on this issue (Table 2) paid particularity attention to the Northern Sea Road (Ho 2009, Verny and Grigentin 2009, Liu and Kronbak 2010, Pierre and Olivier 2015) and Lakhal (2017) has compared the Red-Med railway to the Suez Canal foe the case of the 4000 TFE vessels containers. These researchers studied the case of container vessels on the side of the carrier (the owner ship) and considered the case of LNG. 
Table 2 The most important research on maritime routes comparison

\begin{tabular}{|c|c|c|c|}
\hline Problem analysed & Author & Conclusion or the results achieved & Methodology \\
\hline $\begin{array}{l}\text { Does Red-Med railway could } \\
\text { compete the Suez Canal? }\end{array}$ & Lakhal (2017) & $\begin{array}{l}\text { For the case for a } 4000 \text { TFE Vessel containers, } \\
\text { the transit time the Red-Med railway could } \\
\text { compete the Suez, but (ii) the transfer would cost } \\
\text { approximately three time more than transit } \\
\text { through the Suez Canal. }\end{array}$ & $\begin{array}{l}\text { Comparative case studies using } \\
\text { Relative time and costs analyze. }\end{array}$ \\
\hline $\begin{array}{l}\text { Analysis the benefits of sailing north } \\
\text { via the Northern Sea Route (NSR) } \\
\text { or south via the Suez Canal Route } \\
\text { (SCR) when transporting oil } \\
\text { products from Russia to Asia. }\end{array}$ & $\begin{array}{l}\text { (Faury and Cariou } \\
2016)\end{array}$ & $\begin{array}{l}\text { The NSR provides a competitive advantage in the } \\
\text { months from August to November when } \\
\text { conservative assumptions on ice conditions } \\
\text { (higher bound) are considered for the level of ice } \\
\text { thickness encountered along the route and from } \\
\text { July to November when a lower bound is } \\
\text { assumed. }\end{array}$ & $\begin{array}{l}\text { Analysis of the cost and transit } \\
\text { time savings that change } \\
\text { monthly per sailing conditions } \\
\text { and the area along the NSR. }\end{array}$ \\
\hline $\begin{array}{l}\text { Profit estimation model for } \\
\text { containership sailing from an } \\
\text { original port to a destination port } \\
\text { with multiple port calls and a cost } \\
\text { estimation model for oil tanker } \\
\text { sailing from an origin port to a } \\
\text { destination port. } \\
\text { Comparison of the shipping } \\
\text { efficiency between the Northern } \\
\text { Sea Route (NSR) and the Asia- } \\
\text { Europe shipping route via Suez } \\
\text { Canal. }\end{array}$ & $\begin{array}{l}\text { (Zhang, Meng et al. } \\
\text { 2016) }\end{array}$ & $\begin{array}{l}\text { The NSR shipping is not economically favored } \\
\text { compared to traditional one in container shipping, } \\
\text { but may be only appealing to small or medium- } \\
\text { size tanker operators. }\end{array}$ & $\begin{array}{l}\text { Models development and the } \\
\text { use of real shipping operational } \\
\text { data. }\end{array}$ \\
\hline Assessing the potential of the NSR. & (Zhao, Hu et al. 2016) & $\begin{array}{l}\text { This study's conclusions may prove useful for } \\
\text { strategic planning by liner companies, port } \\
\text { authorities, and governments to assess the } \\
\text { operation of liner service via the NSR. }\end{array}$ & $\begin{array}{lc}\text { Developing a } & \text { two-stage } \\
\text { optimization model. } & \end{array}$ \\
\hline $\begin{array}{l}\text { Cost analysis of the Northern Sea } \\
\text { Route and the Suez Canal Route. }\end{array}$ & $\begin{array}{l}\text { (Furuichi and Otsuka } \\
2015 \text { ) }\end{array}$ & $\begin{array}{l}\text { Northern Sea Route I Suez Canal Route } \\
\text { NSR/SCR-combined shipping of container cargo } \\
\text { between East Asia and Northwest Europe can be } \\
\text { commercially feasible. }\end{array}$ & $\begin{array}{l}\text { Analysing the cost components } \\
\text { contained in the current } \\
\text { literature. }\end{array}$ \\
\hline $\begin{array}{l}\text { Analysis of transportation risks, } \\
\text { safety, and security Northern Sea } \\
\text { Route. }\end{array}$ & $\begin{array}{l}\text { (Hill, Lanore et al. } \\
\text { 2015) }\end{array}$ & $\begin{array}{l}\text { As current global trade routes through the } \\
\text { Panama and Suez Canals reach capacity, we do } \\
\text { not doubt that capital investment into the NSR will } \\
\text { increase and it will become an attractive and } \\
\text { efficient transportation option for international } \\
\text { markets. }\end{array}$ & $\begin{array}{l}\text { Review of the existing studies } \\
\text { on the Northern Sea Route, } \\
\text { discuss these risks and } \\
\text { challenges. }\end{array}$ \\
\hline $\begin{array}{l}\text { Identifying the economic, external, } \\
\text { and internal drivers and barriers to } \\
\text { voyage through the NSR, from the } \\
\text { perspective of shipping companies. }\end{array}$ & (Lee and Kim 2015) & $\begin{array}{l}\text { The differences between shipping companies that } \\
\text { consider voyaging the NSR mainly lie in } \\
\text { companies' perceptions of economic } \\
\text { opportunities and their internal factors. }\end{array}$ & $\begin{array}{l}\text { Comparative case studies, } \\
\text { using interviews and document } \\
\text { analysis. }\end{array}$ \\
\hline $\begin{array}{l}\text { Spot freight rate to fuel ratio and the } \\
\text { NSR. }\end{array}$ & $\begin{array}{l}\text { (Pierre and Olivier } \\
\text { 2015) }\end{array}$ & $\begin{array}{l}\text { Internalizing NSR environmental benefits } \\
\text { marginally improves the attractiveness of the } \\
\text { NSR. }\end{array}$ & $\begin{array}{l}\text { Mathematical } \\
\text { optimisation. }\end{array}$ \\
\hline $\begin{array}{l}\text { The potential positive economic } \\
\text { effects of NSR. }\end{array}$ & (Lee and Song 2014) & $\begin{array}{l}\text { The NSR has economic effects in terms of } \\
\text { distance and time, but the factor of expensive } \\
\text { NSR toll fees imposed by Russia should be } \\
\text { considered. }\end{array}$ & $\begin{array}{l}\text { Analysis of the cost and transit } \\
\text { time savings. }\end{array}$ \\
\hline $\begin{array}{l}\text { Implication analysis of the opening } \\
\text { of the Northern Sea Route on } \\
\text { maritime sector of the Malaysian } \\
\text { economy. }\end{array}$ & $\begin{array}{l}\text { (Rahman, Saharuddin } \\
\text { et al. 2014) }\end{array}$ & $\begin{array}{l}\text { The opening of the Northern Sea Route as an } \\
\text { alternative route for transporting cargoes from the } \\
\text { Far East and Europe will affect the maritime } \\
\text { sector of Malaysia's economy in scope of 1) } \\
\text { political, 2) economy, 3) social, 4) technology 5) } \\
\text { environment and 6) legal. }\end{array}$ & $\begin{array}{l}\text { PESTLE : Political Economic } \\
\text { Social Technological, Legal } \\
\text { Environmental analysis. }\end{array}$ \\
\hline $\begin{array}{l}\text { Implications of Northern Sea Routes } \\
\text { on the Korea's shipping industry. }\end{array}$ & (Ha and Seo 2014) & $\begin{array}{l}\text { The number of voyages range from over } 2,900 \text { to } \\
\text { as little as } 237 \text { for Europe-17, depending on } \\
\text { vessel sizes, when NSR is available for the whole } \\
\text { year. }\end{array}$ & Cost an capacity analysis. \\
\hline $\begin{array}{l}\text { Perspectives of Northern Sea Route } \\
\text { and Northwest Passage in the } \\
\text { twenty-first century. }\end{array}$ & $\begin{array}{l}\text { (Khon, Mokhov et al. } \\
\text { 2010) }\end{array}$ & $\begin{array}{l}\text { The transit through the NSR from Western Europe } \\
\text { to the Far East may be up to } 15 \% \text { more profitable } \\
\text { in comparison to Suez Canal transit by the end of } \\
\text { the twenty-first century. }\end{array}$ & A simulations model. \\
\hline $\begin{array}{l}\text { Verifies the technical and economic } \\
\text { feasibility of regular container } \\
\text { transport along the NSR }\end{array}$ & $\begin{array}{l}\text { (Verny and Grigentin } \\
\text { 2009) }\end{array}$ & $\begin{array}{l}\text { While shipping through the Suez Canal is still by } \\
\text { far the least expensive option, the NSR and } \\
\text { Trans-Siberian Railway appear to be roughly } \\
\text { equivalent second-tier alternatives }\end{array}$ & $\begin{array}{l}\text { Relative costs analyze of } \\
\text { various axes in the Asia-Europe } \\
\text { transport network, including the } \\
\text { NSR }\end{array}$ \\
\hline
\end{tabular}




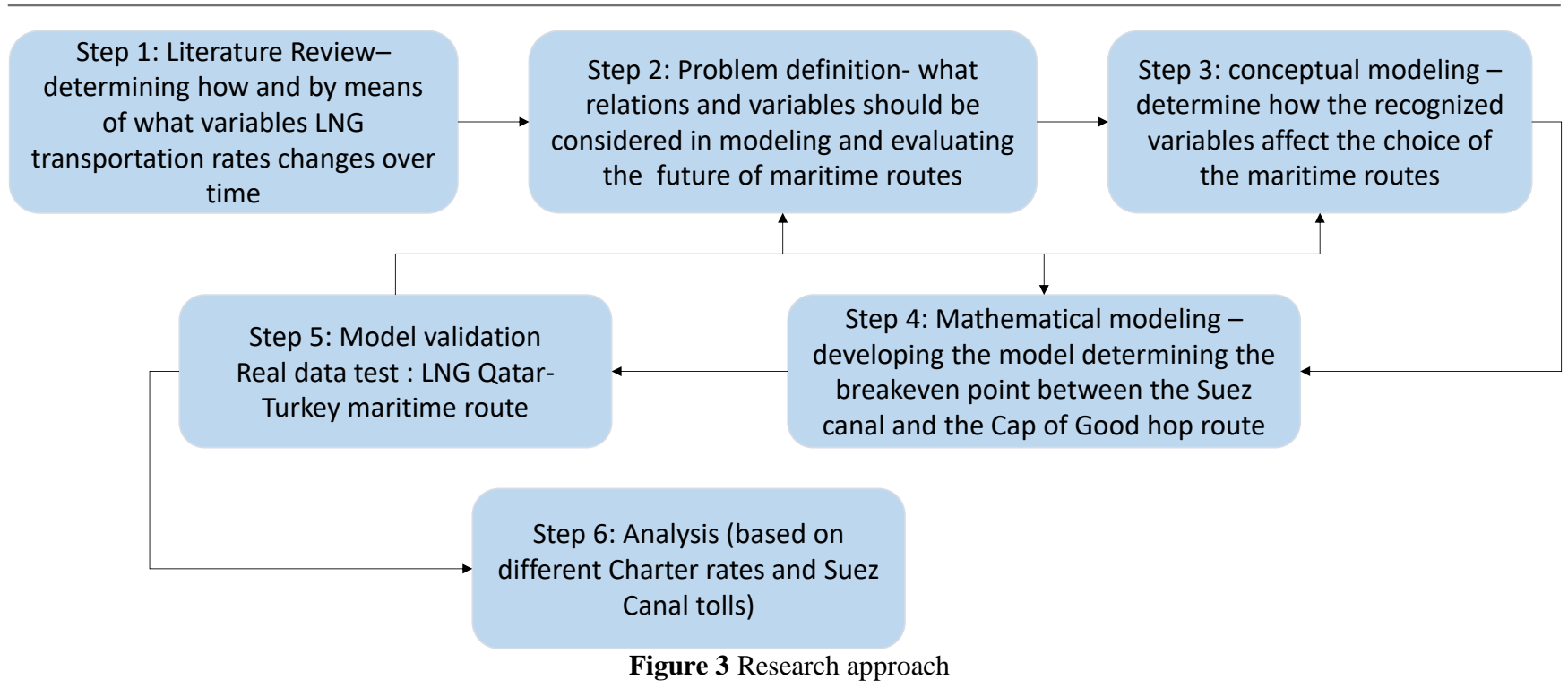

For the LNG transport, which is our case, we have a direct service transport from one port to another, we have also one shipper which is easier for the carrier to deal with in case of problems. In contrary, in the case of containers vessel, we may have hundreds of shippers and many ports to visit before arriving to the last one. This paper treats the shipper side and suggest a simple model easy to understand and to implement using few and public data very easy to gather for frequent decisions.

\section{METHODOLOGY}

Primary research methodology of this study is designing a maritime route to transport LNG from the Middle East gas fields to Europe using a mathematical model and data collection, from available public sources or estimated data based on public sources. The data is estimated through three ways: measurement and calculation (e.g., the shipping distance), literature studies (e.g., fuel consumption), and industry investigation (e.g., the freight rate, tanker speed insurance).

The research process and the outline paper are illustrated in Figure 3. The steps involved in this research approach are as follows:

1. Determine the distances of two voyage routes one should be through the Suez Canal,

2. Determine the market bunker fuel price in USD per ton,

3. Determine the optimal vessel speed to be considered in the analysis,

4. Determine the insurance rates for each route including the piracy insurance premium,

5. Determine the Suez Canal tolls

6. Calculate LNG charter rate breakeven point equalizing the two route costs,

7. Determine the market LNG charter,

Choose the Suez Canal route if the market LNG charter is greater than LNG charter rate breakeven point. Otherwise choose the alternative route.

\section{THE MODEL}

To consider the case of LNG maritime transport by LNG we make the following assumptions:

a) Considering the LNG is not perishable product; the lead time will not influence the decision of the maritime route. Furthermore, the LNG Tankers are considered as "floating pipeline", then a high lead time will be compensated by increasing the number of the vessels in service,

b) The analysis is made for the shipper view and interest,

c) The charter rate paid by the shipper to the carrier covers all the vessel costs (bunker, insurance for the vessel and demurrage),

d) The Suez Canal transit tolls, the cargo insurance premium and piracy insurance premium are paid by the shipper,

e) The shipper does not own the vessels, then it has no other cost (more than listed in (iii)) to pay,

f) The LNG shipper has a delivery long term contract with the customer then, the cost of the LNG inventory in transit is supported by the shipper and not considered in the analysis,

g) Finally, the environment respects are considered by the shipper and the carrier and reflected in the charter rate which could be majored to reflect the right speed.

The variables used in the model are defined in the following Table 3.

Table 3 The variable definition

\begin{tabular}{|l|l|l|}
\hline & $\begin{array}{c}\text { Suez Canal } \\
\text { Route }\end{array}$ & $\begin{array}{l}\text { Cape of Good } \\
\text { Hope }\end{array}$ \\
\hline $\begin{array}{l}\text { Round trip Distance in } \\
\text { Nmiles }\end{array}$ & Ds & Dc \\
\hline $\begin{array}{l}\text { Average speed (knots per } \\
\text { hour) }\end{array}$ & $V$ & $V$ \\
\hline $\begin{array}{l}\text { LNG charter Rates USD per } \\
\text { day }\end{array}$ & $R$ & $R$ \\
\hline $\begin{array}{l}\text { Suez Canal Toll per round } \\
\text { trip voyage }\end{array}$ & $T$ & $I C$ \\
\hline Insurance & IS & \\
\hline
\end{tabular}


For a round trip the two routes are equivalent for the shipper when the cost are equal:

$\frac{2 D s}{24 V} R+T+I s=\frac{2 D c}{24 V} R+I c$

Let $\mathrm{X}=\frac{R}{12 V}$ then $D s X+T+I S=D c X+I c$

And $\mathrm{X}$ will be $X=\frac{T+I s-I c}{D c-D s}$

The breakeven point leading to equalize the cost between the two roots: the Suez Canal and the cap of the good hope is $\quad R^{*}=12 \mathrm{~V} \frac{T+I s-I c}{D c-D s}$

\subsection{Discussion the Term $R$ (Charter Rate)}

The LNG Charter rates is a market parameter. According to Stokes and Spinks (2015) this parameter depends mainly on the fleet utilization and the LNG new build vessels projects, the gas projects scheduled to start over the next six months, the oil price and the LNG demand.

For example, in 2015 (Figure 4) the spot charter rates fall to USD 25,000 per day and term charter rates (12 mths+) have fallen below USD 40,000 per day. These rates are too low compared to their peak above USD 140,000 in the mid2012s. This rate is similar to the levels seen within the depths of the global financial crisis in 2008. These rates are too low if we consider a breakeven cost for delivering new vessels is estimated -according to (Stokes and Spinks 2015) - to be around USD 60,000 to USD 70,000 per day.

\section{Freight rates 1,000 USD/day}

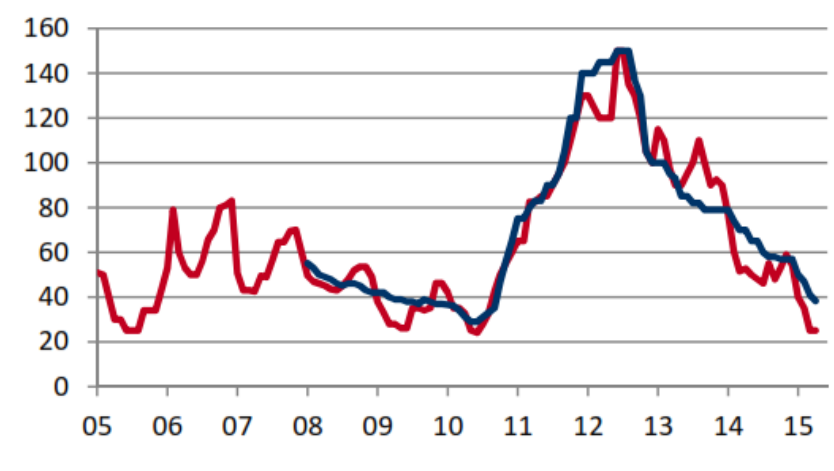

Spot, 145k steam $12 \mathrm{~m} \mathrm{T/C}, 160 \mathrm{k}$ DFDE

Figure 4 LNG spot and term time charter rates

Lindstad and Eskeland (2015) (based on conversations with industry practitioners) state that: in freight contracts, agreements are made on speed. The agreement, in principle, allows cargo owner's concerns for delivery time and capital tied in cargo to influence speed. But in practice, this speed agreement may be dominated by routine, and thus being sluggish and leaving room for discretion to ship-owner.

\subsection{Discussion the Term V (Average Speed)}

For each vessel, there is a normal speed called "boundary speeds" based on hydrodynamic considerations that could be different from the optimal speed minimising the fuel consummation. We extended the work of Lindstad and Eskeland (2015) to derive the following graph indicating the optimal fuel consumption of an Aframax vessels (Figure 5).

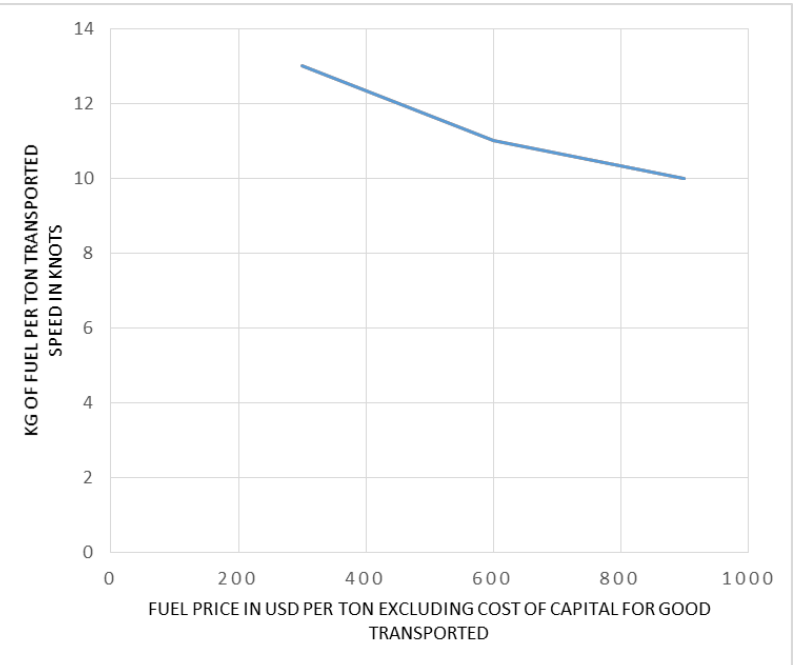

Figure 5 Optimal fuel consumption and speed for standard Aframax vessel

\subsection{Discussion the tTerm T (Suez Canal Toll per Round Trip Voyage)}

The Suez Canal Authority levies tolls based essentially on the vessels type (container ship, LNG ship, etc.) net tonnage and the gross tonnage. Furthermore, the tolls is significantly different if the ship is going North (to the Mediterranean see) or South (to the Red-See) and if it laden or ballast. The ship should respect the Suez max dimensions. The charge is highest for the first 5,000 tons, then decreases as the tonnage rises. Add-ons are plentiful, including pilot and port fees, pay for an electrician to operate a searchlight on the bow at night, surcharges for deck cargo such as boats, and penalties for showing up late for convoy formation.

\subsection{Discussion the Term Ic and Is}

$I_{c}$ and $I_{s}$ are respectively the insurance premiums to cover the cargo for the voyage through the Cape of Good Hope and the Suez Canal. The premiums depend on the piracy risk and the war risk of each route. For example, and according to our investigation, the premium to cover a war and terrorism medium risk could be USD 25,000 per voyage.

\section{THE MODEL TEST}

To test our model, we consider a service from Qatar to Turkey for LNG vessels. Qatar is an important gas producer and is looking to have access to the European Market satisfied mainly by Russia for around 40\% (Bridier 2014). Russia is also a big gas provider for Turkey which importing $55 \%$ of its consumption (27 bcm per year) from Russia (Okumuş 2015). In November 24, 2015, Turkey shot down a Russian warplane on the Syrian border for violating Turkish airspace. After this incident, Russia started economic sanctions against Turkey. Consequently, the Russian gas flow to Turkey is not any more assured. Turkey started looking for new providers. Due to the good relations between Turkey and Qatar the Qatari gas is a very good opportunity to replace the Russian one. Two routes are candidate: the route through the Suez Canal and the route via the Cape of the Good Hope. 


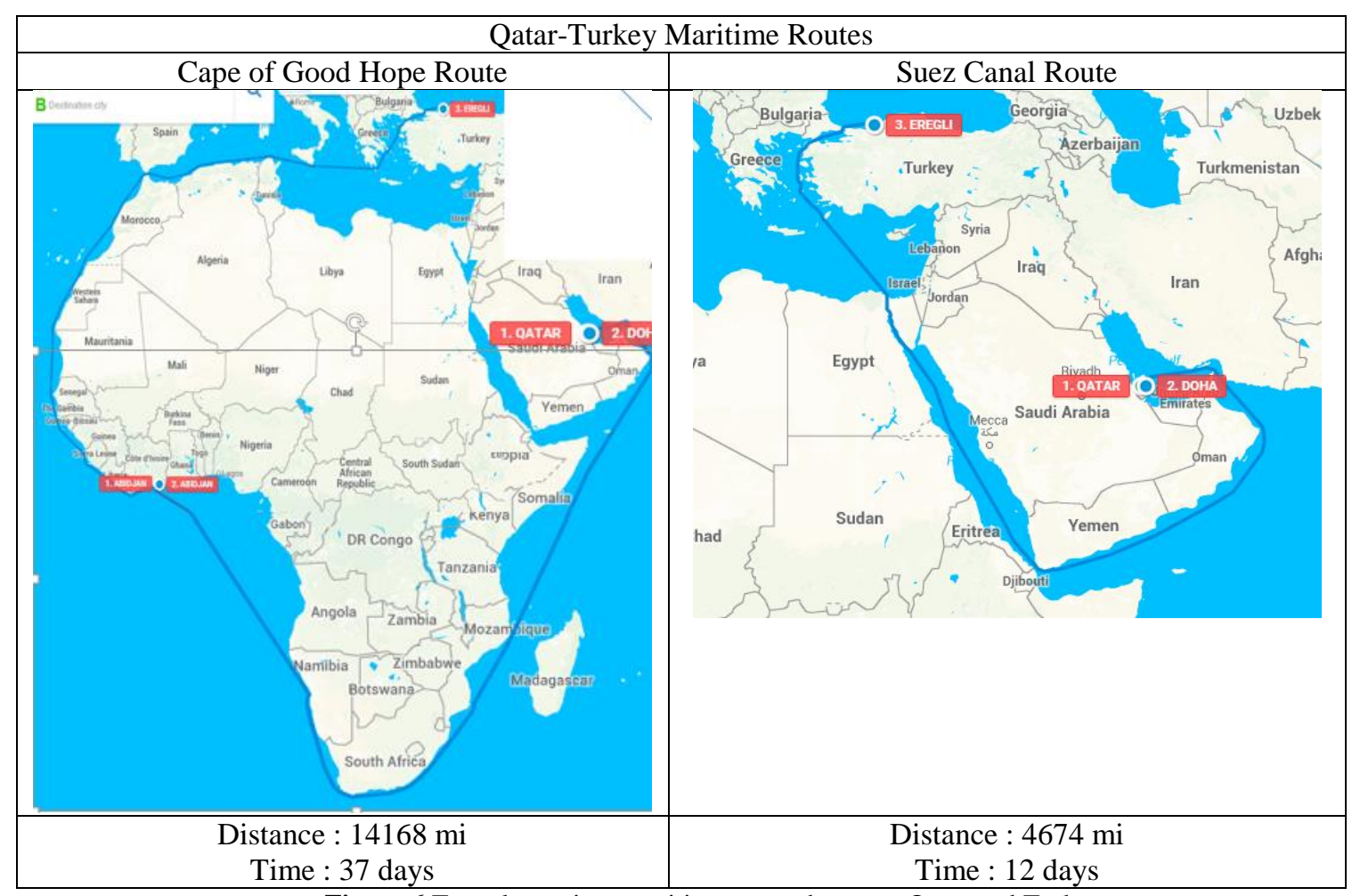

Figure 6 Two alternatives maritime routes between Qatar and Turkey

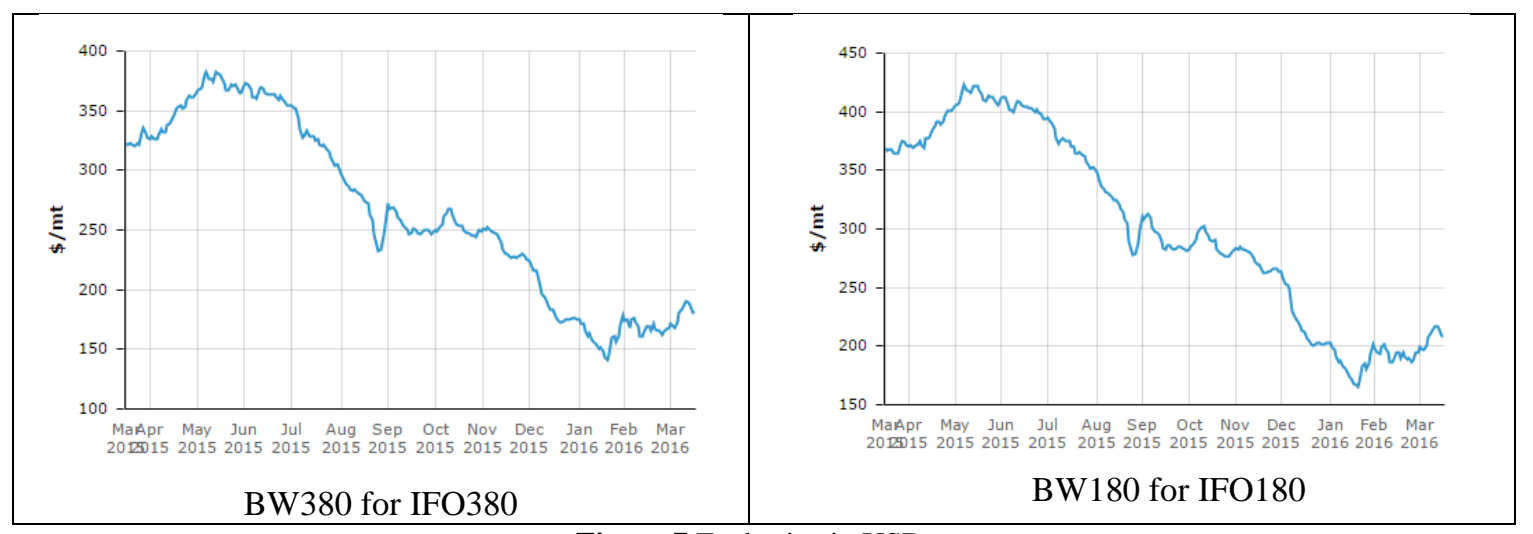

Figure 7 Fuel price in USD per ton

\section{Step 1: The Distance Between Qatar and Turkey}

We consider the LNG will be transported from Qatar to the port of Ereğli is $30 \mathrm{~km}$ east of the town of Tekirdağ, and $90 \mathrm{~km}$ west of Istanbul near a small pointed headland on the north shore of the Marmara Sea. It is called Marmara Ereğlisi (or Marmara Ereğli in colloquial usage). This port is quite big to service the LNG tanker. Two routes (Figure 6) are candidates: through the Suez Canal or via the Cap of Good Hope. Using the website www.searates.com/2 we can determine the distance between Qatar and Marmara Ereğli. It is $14,168 \mathrm{mi}$ via the Cape of Good Hope route and only 4,674 mi through Suez Canal.

\section{Step2: The Market Price of the Bunker Fuel}

Bunker is the name given to the Fuel that is used to operate ships. There are various types of fuel oil and within the fuel oils, there are many classifications, standards and grades: $M G O$ (Marine gas oil), MDO (Marine diesel oil), IFO (Intermediate fuel oil), MFO (Marine fuel oil), HFO (Heavy fuel oil). Most vessels use the IFO180 and the IFO380 grades (Braden 2016, Effendy, Khan et al. 2017).
There is many website publishing a daily price of the fuel bunker like http://shipandbunker.com or http://www.bunkerworld.com/prices/ (Figure 7) presents the bunker word index for the IFO180 and the IFO380 during 2015 and 2016. The bunker IFO380 is the most used bunker, it represent $80 \%$ of the vessels use.

\section{Step 3. The Determination of the Vessel Speed}

The bunker fuel price gives the possibility to determine an optimal speed. This speed is set jointly for cargo-owner and ship-owner, as would be economically efficient from society's perspective. This possibility can be envisaged concretely, for instance as they agree on a speed in the contract called the charter party. If we consider a bunker IFO380 with a price USD 180 per metric tons, and using the graph of Figure 5 the optimal speed will be 13.5 knots.

On the other hand, if we use the distance and the time of each voyage calculated by the www.searates.com indicated in Step 1 to calculate the average speed, we find 16 knots per hour. These two speeds calculated is less than the average speed in practice by the LNG vessels in mars 2016 

Operations and Supply Chain Management 11(1) pp. 13 - 25 @ 2018

per the information from the website www.marinetraffic.com. Therefore, we calculated this speed for the ten Qatari LNG vessels (Al Zubarah, Al Rayyan, Al Wajbah, Broog, Al Khor, Al Wakrah, Zekreet, Doha, Al Bidda, Al Jasra)) and we have found an average speed equal to 18 knots.

This difference in the speeds calculated could be explained by: $(i)$ Figure 5 used to calculate the optimal speed is developed for an Aframax vessel and not an LNG Vessel and, (ii) the speed 16 knots calculated using the information from the website www.searates.com is an average speed with no specification of the vessels type. These give more credibility to the average speed calculated (18 knots) for the LNG vessels.

\section{Step 4. The Determination of the Insurance Premium}

The Basics insurance offer a variety of mechanisms used to insure vessels: hull insurance, cargo insurance, liability coverage (protection and indemnity P\&I), and war risk insurance. The war risk covers the piracy risk. Insurance rates are based on tangible factors such as deadweight tonnage (dwt) and the overall value of the ship itself, as well as what sort of coverage a tanker on a particular voyage needs. These tangible aspects of LNG tanker vessels insurance are relatively uniform across ships of equal size and tonnage. Other coverage, such as liability and war risk factors, are more variable and dynamic, as they change based on the geographical location or route of the ship. War risk covering the piracy risks are generally excluded from hull the standard insurance policies. Therefore, it must be purchased in addition to standard liability coverage.

\section{War Risk Insurance}

A "war risk premium" is meant to cover any intentional damage to hull, cargo or the vessel crew. For the most part, every policy includes some nominal war risk coverage, based on trading routes and patterns. According to the https://www.warrisk.no/cover/ specialised on covering the war risks, when the risk profile of a vessel is extremely low, the premium can be as low as $0.001 \%$ of the market value of the vessel.
The global risk is reassessed each year for each area and will require vessel charter companies to pay additional fees. The additional fees area may be designated in any number of ways, specifying particular countries, ports or even regions. A policy of war risk insurance is offered for a limited of time (usually between 48 hours and seven days). At the end of period, the insurance could be renewed if it is necessary.

The premium of the additional premium depends on the level of risk perceived by the insurance underwriter. These additional premiums can reach ten percent $(10 \%)$ of the market value of the vessel if the area is considered very risky. For example, according to the website www.strausscenter.org/hormuz/insurance-market.html : in (2008) the territorial waters of Somalia was one of the most expensive additional premium areas, the war premium insurance was approximately (2\%) two percent of market value of the vessel for a seven-day policy. For example, a $100,000,000$ vessel at port in Somalia for 20 days, the insurance war risk premium was USD 6,000,000, which is considered expensive.

The investigation of the risk war of our routes for 2016 leads to the Suez canal route seems to be low risk area according to the ICC (2016) (Figure 8). In 2015 and 2016 there is no incident registered.

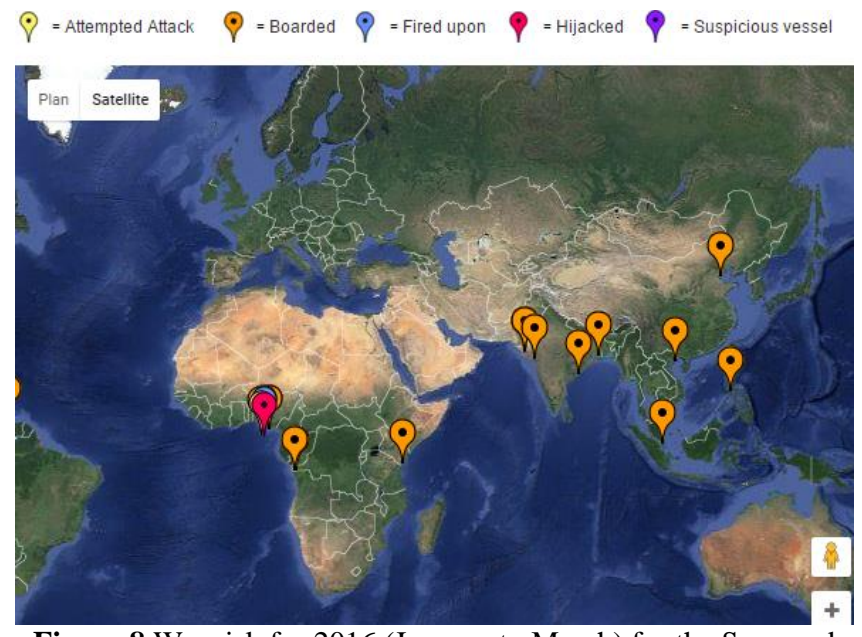

Figure 8 War risk for 2016 (January to March) for the Suez and the Cape of Good Hope Routes, adapted from ICC (2016).

Table 4 The piracy numbers registered on the Suez Canal and Cape of Good Hope routes

\begin{tabular}{|r|r|r|r|r|r|}
\hline \multicolumn{1}{|c|}{ Locations } & 2011 & 20012 & 2013 & 1014 & 1015 \\
\hline Suez Canal route & & & & & \\
\hline Egypt & 3 & 7 & 7 & & 1 \\
\hline Gulf of Aden* & 37 & 13 & 6 & 4 & \\
\hline Red Sea* & 39 & 13 & 2 & 4 & \\
\hline Somalia* & 160 & 49 & 7 & 3 & \\
\hline Oman* & 1 & & & 2 & \\
\hline Total for Suez Canal route & 240 & 82 & 22 & 13 & 1 \\
\hline Cap Of Good Hope route & & & & & \\
\hline Algeria & & 1 & & & \\
\hline Angola & 1 & & & 1 & \\
\hline Benin & 20 & 2 & & & \\
\hline Cameroon & & 1 & & 1 & 1 \\
\hline
\end{tabular}




\begin{tabular}{|c|c|c|c|c|c|}
\hline Locations & 2011 & 20012 & 2013 & 1014 & 1015 \\
\hline Dem. Rep. Of Congo & 4 & 2 & & 1 & 3 \\
\hline Dem. Rep. Of Sao Tome \& Principe & & & & 1 & \\
\hline Gabon & & & 2 & 1 & \\
\hline Ghana & 2 & 2 & 1 & 4 & 2 \\
\hline Guinea & 5 & 3 & 1 & & 3 \\
\hline Ivory Cost & 1 & 5 & 4 & 3 & 1 \\
\hline Kenya & 1 & 1 & 1 & & 2 \\
\hline Liberia & & & & 1 & 2 \\
\hline Mauritania & & & 1 & & \\
\hline Morroco & & & 1 & 1 & \\
\hline Mozambique & & 2 & 2 & 1 & 1 \\
\hline Nigeria & 10 & 27 & 31 & 18 & 14 \\
\hline Sierra Leone & 1 & 1 & 2 & 1 & \\
\hline Tanzania & & 2 & 1 & 1 & \\
\hline The Congo & 3 & 4 & 3 & 7 & 5 \\
\hline Togo & 6 & 15 & 7 & 2 & \\
\hline Rest of Mediterranean Sea & 1 & & & & \\
\hline Papua New Guinea & & & & & 1 \\
\hline Total for the Cap of the Good Hope route & 55 & 68 & 57 & 44 & 35 \\
\hline
\end{tabular}

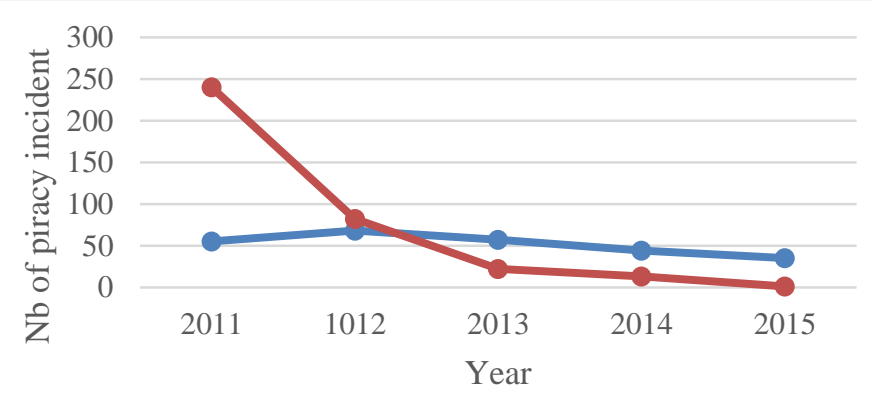

$\longrightarrow$ Cape of Good hope route $\quad \longrightarrow$ Suez Cnal route

Figure 9 Comparison of the piracy numbers between the Suez Canal and the Cape of Good Hope Routes

Table 5 Qatar gas LNG vessels dimensions and characteristics

\begin{tabular}{|l|l|}
\hline Length (O.A.) & Dimensions and characteristics \\
\hline Breadth (moulded) & $297.50 \mathrm{~m}$ \\
\hline Depth (moulded) & $45.75 \mathrm{~m}$ \\
\hline $\begin{array}{l}\text { Designed Draft } \\
\text { Gross Tonnage }\end{array}$ & $25.50 \mathrm{~m}$ \\
\hline $\begin{array}{l}\text { Dead Weight Tonnage at Designed } \\
\text { Draft }\end{array}$ & $10.95 \mathrm{~m}$ \\
\hline LNG Tank Capacity & About 112,200 tonnes \\
\hline Speed & About 135,000 tonnes $\mathrm{m}^{3}\left(-163^{\prime} \mathrm{C}, 98.5 \%\right)$ \\
\hline
\end{tabular}

The evolution of piracy through the red sea and the Gulf of Aden attacks related to Somali pirates have reduced since 2011 (see Table 4 and Figure 9). There is no attack in 2015 and the first quarter of 2016 however, the risk still exists.
Considering the Cape of the Good Hope route, the number of attacks is reduced from 55 attacks in 2011 to 35 in 2015, Nigeria costs remains the most risky area with $40 \%$ of attacks. Considering all this information available we 

Operations and Supply Chain Management 11(1) pp. 13 - 25 @ 2018

consider that the amount paid for all kind of insurance for the route around the Cape of Good Hope $I_{c}$ will be greater than the Suez Canal Route $I s$ and the difference $I_{s}-I_{c}$ in the equation (2) will be a negative amount.

\section{Step 5. The Determination of the Suez Canal Toll}

Qatargas (www.qatargas.com) is the state company established in 1984, pioneered the Liquefied Natural Gas (LNG) Industry in Qatar. Today, Qatargas is the largest LNG producing company in the world, with an annual LNG production capacity of 42 million tons per annum (MTA). Qatargas owns ten LNG Tanker the name of each vessels reflects the main cities and areas in Qatar like Al Khor and Doha. Each vessel has the following dimensions and characteristics (Table 5).

Using the online tolls calculation related to the Suez Canal (Figure 5) on March 20, 2016 the toll for Northern laden voyage USD 674,326 and for southern ballast voyage is USD 552,446 giving a total for a round trip voyage USD $1,226,772$.

\section{Step 6. LNG Charter Rate Breakeven Point Equalizing the Two Route Costs}

As indicated in step $4, I_{c}$ will be greater than $I s$ due to the greater piracy risk around the Cape of Good Hope route. Then we make this transformation $T+I_{s}-I_{c}=T-\left(I_{c}-I_{s}\right)$, it indicates the toll payed to take the Suez Canal short will be reduced by the difference of the insurances (Insurances premium via The Cape of the Good Hope minus Insurances Premium through the Suez Canal).

Therefore equation 3 becomes

$$
R^{*}=12 V \frac{T-(I c-I s)}{D c-D s}
$$

To calculate $R^{*}$, we consider that the average vessel speed $V$ could vary between 10 and 20 Knots depending on the fuel price and the technical characteristics of the vessel. Furthermore for the $T-\left(I_{c}-I_{S}\right)$, we consider a variation between USD 800,000 to USD 1,700,000.

The calculation presented in Table 6 indicates that the maximum $R^{*}=\mathrm{USD} 42,975$ is for $T-\left(I_{c}-I_{s}\right)=\mathrm{USD}$ $17,000,000$ and an average speed $V=20$ knots per hour. The minimum $R^{*}=\operatorname{USD} 10,112$ is for $T-\left(I_{c}-I_{s}\right)=\operatorname{USD} 80,000$ and an average speed $V=10$ knots per hour.

We compare our result to some professional thoughts. For example James Allan, a gas ship broker at London-based Galbraith says according to Paris (2014) “...with a breakeven point of USD 40,000 to USD 50,000 per day, it was party time for owners." On the other hand and according to Stokes and Spinks (2015), the breakeven for a new vessels is around USD 60,000 to USD 70,000 per day. The same estimation is made by Wallis (2015) reporting that LNG tankers need to earn USD 60,000 to USD 80,000 a day to cover capital and operating costs.

These results should be compared to the LNG charter freight rate to decide which route will be chosen.

\section{Step 7. The Market LNG Charter}

In the end of 2015 and in the first quarter the LNG charter has been in its worst downturn in 30 years (Wallis
2015). According to data from British shipping services firm Clarkson Wallis (2015) reports that Spot charter rates for a $160,000 \mathrm{~m}^{3}$ LNG carrier are currently around USD 32,000 per day in the end of December 2015, down from USD 72,000 in 2014 and over USD 100,000 in 2013. This is concurring with other sources (Stokes and Spinks 2015) discussed above indicating a rate between 20 and USD 40,000 per day which is less than the breakeven point as indicated in the Step 6 section. This low rates explain why more vessels are avoiding the Suez Canal route and choosing the Cape of Good Hope route. This situation will not be a steady state and will lead to more mergers and acquisitions, more consolidation and a lot more joint ventures and the rates will increase above the USD 60,000 per day rate.

\section{Step 8. The Most Economical Route}

For a maritime route service from Qatar to Turkey, if the LNG charter rate is between 20 and USD 40,000 per day and considering a Suez Canal tolls for a round trip more than USD 1,700,000, it is cost efficient to use the Cape of Good Hope route. Otherwise, we use the Suez Canal. We say more than USD $1,700,000$ because in our calculation we considered $T-\left(I_{c}-I_{S}\right)=$ USD $1,700,000$.

\section{GENERAL DISCUSSION}

As illustrated, the use of the framework and the model developed is not complicated and the data is relatively easy to gather which is the strongest feature of this paper's approach. We preferred this to finding other researchers comparing the maritime route around the Cape of Good Hope to the Suez Canal routes to confront our result with, but it is not the case. Our results show that the Cape of Good Hope route is a fervent competitor to the Suez Canal especially when the LNG charter rate is between 20 and USD 40,000. Adjusting the tolls remains the best tool for the Suez Canal to neutralise the Cape of Good Hope route competition. But, considering that the Suez Canal is an important source of currency for Egypt, the action range stays limited. Furthermore, as shown in the literature review, there is another competitor in perspective for the Canal Suez route which is the North Sea Route for a transport to Europe from the Far East countries especially China, South Korea and Japan. Considering that the LNG is produced in the Middle East, the North Sea Route will not affect the LNG maritime route for a transport to Europe from the Middle East gas fields, which is good news for our results.

The model developed could be used for any route where the transit through the Suez Canal is an option. For example, for the route Qatar-Rotterdam the difference between the two distance is only $D_{c}-D_{s}=4,600$ miles. In this case, the breakeven point will be USD 80,000 per day for a speed $V=$ 18 knots per hour and a Suez Canal tolls adjusted by the premium insurance difference T $-\left(I_{c}-I_{s}\right)=$ USD 1,700,000. For the Europe routes from Asia, a charter rate equal or more than USD 80,000 per day will be profitable for the carrier knowing that the carrier need to earn, according to Wallis (2015), USD 60,000 - USD 80,000 a day to cover capital and operating costs. 
Table 6 The breakeven point of LNG charter rates USD per day $\left(R^{*}\right)$

\begin{tabular}{|c|c|c|c|c|c|c|c|c|c|c|c|}
\hline$T$-(ic-ls) & V & Dc-Ds & $R^{*}$ & $T$-(ic-Is) & V & Dc-Ds & $R^{*}$ & $T$-(ic-Is) & V & Dc-Ds & $R^{*}$ \\
\hline 800000 & 20 & 9494 & 20223 & 800000 & 19 & 9494 & 19212 & 800000 & 18 & 9494 & 18201 \\
\hline 900000 & 20 & 9494 & 22751 & 900000 & 19 & 9494 & 21614 & 900000 & 18 & 9494 & 20476 \\
\hline 1000000 & 20 & 9494 & 25279 & 1000000 & 19 & 9494 & 24015 & 1000000 & 18 & 9494 & 22751 \\
\hline 1100000 & 20 & 9494 & 27807 & 1100000 & 19 & 9494 & 26417 & 1100000 & 18 & 9494 & 25026 \\
\hline 1200000 & 20 & 9494 & 30335 & 1200000 & 19 & 9494 & 28818 & 1200000 & 18 & 9494 & 27301 \\
\hline 1300000 & 20 & 9494 & 32863 & 1300000 & 19 & 9494 & 31220 & 1300000 & 18 & 9494 & 29577 \\
\hline 1400000 & 20 & 9494 & 35391 & 1400000 & 19 & 9494 & 33621 & 1400000 & 18 & 9494 & 31852 \\
\hline 1500000 & 20 & 9494 & 37919 & 1500000 & 19 & 9494 & 36023 & 1500000 & 18 & 9494 & 34127 \\
\hline 1600000 & 20 & 9494 & 40447 & 1600000 & 19 & 9494 & 38424 & 1600000 & 18 & 9494 & 36402 \\
\hline 1700000 & 20 & 9494 & 42975 & 1700000 & 19 & 9494 & 40826 & 1700000 & 18 & 9494 & 38677 \\
\hline$T$-(ic-ls) & $V$ & Dc-Ds & $R^{*}$ & $T$-(ic-ls) & $V$ & Dc-Ds & $R^{*}$ & $T$-(ic-Is) & $V$ & Dc-Ds & $R^{*}$ \\
\hline 800000 & 17 & 9494 & 17190 & 800000 & 16 & 9494 & 16179 & 800000 & 15 & 9494 & 15167 \\
\hline 900000 & 17 & 9494 & 19339 & 900000 & 16 & 9494 & 18201 & 900000 & 15 & 9494 & 17063 \\
\hline 1000000 & 17 & 9494 & 21487 & 1000000 & 16 & 9494 & 20223 & 1000000 & 15 & 9494 & 18959 \\
\hline 1100000 & 17 & 9494 & 23636 & 1100000 & 16 & 9494 & 22246 & 1100000 & 15 & 9494 & 20855 \\
\hline 1200000 & 17 & 9494 & 25785 & 1200000 & 16 & 9494 & 24268 & 1200000 & 15 & 9494 & 22751 \\
\hline 1300000 & 17 & 9494 & 27933 & 1300000 & 16 & 9494 & 26290 & 1300000 & 15 & 9494 & 24647 \\
\hline 1400000 & 17 & 9494 & 30082 & 1400000 & 16 & 9494 & 28313 & 1400000 & 15 & 9494 & 26543 \\
\hline 1500000 & 17 & 9494 & 32231 & 1500000 & 16 & 9494 & 30335 & 1500000 & 15 & 9494 & 28439 \\
\hline 1600000 & 17 & 9494 & 34380 & 1600000 & 16 & 9494 & 32357 & 1600000 & 15 & 9495 & 30332 \\
\hline 1700000 & 17 & 9494 & 36528 & 1700000 & 16 & 9494 & 34380 & 1700000 & 15 & 9496 & 32224 \\
\hline$T$-(ic-IS) & V & Dc-Ds & $R^{*}$ & $T$-(ic-Is) & V & Dc-Ds & $R^{*}$ & $T$-(ic-Is) & V & Dc-Ds & $R^{*}$ \\
\hline 800000 & 14 & 9494 & 14156 & 800000 & 13 & 9494 & 13145 & 800000 & 10 & 9494 & 10112 \\
\hline 900000 & 14 & 9494 & 15926 & 900000 & 13 & 9494 & 14788 & 900000 & 10 & 9494 & 11376 \\
\hline 1000000 & 14 & 9494 & 17695 & 1000000 & 13 & 9494 & 16431 & 1000000 & 10 & 9494 & 12640 \\
\hline 1100000 & 14 & 9494 & 19465 & 1100000 & 13 & 9494 & 18075 & 1100000 & 10 & 9495 & 13902 \\
\hline 1200000 & 14 & 9494 & 21234 & 1200000 & 13 & 9494 & 19718 & 1200000 & 10 & 9494 & 15167 \\
\hline 1300000 & 14 & 9494 & 23004 & 1300000 & 13 & 9494 & 21361 & 1300000 & 10 & 9494 & 16431 \\
\hline 1400000 & 14 & 9494 & 24774 & 1400000 & 13 & 9494 & 23004 & 1400000 & 10 & 9494 & 17695 \\
\hline 1500000 & 14 & 9495 & 26540 & 1500000 & 13 & 9494 & 24647 & 1500000 & 10 & 9494 & 18959 \\
\hline 1600000 & 14 & 9496 & 28307 & 1600000 & 13 & 9494 & 26290 & 1600000 & 10 & 9494 & 20223 \\
\hline 1700000 & 14 & 9497 & 30073 & 1700000 & 13 & 9494 & 27933 & 1700000 & 10 & 9494 & 21487 \\
\hline
\end{tabular}

\section{CONCLUDING REMARKS}

For the regions where there are no gas pipelines in operation, LNG tankers play an important role in supplying natural gas to regions in short supply and with limited or no domestic production. The Middle East is in this situation and the gas producers could not find a way to supply their natural gas by pipeline to Europe or even Turkey due to a turbulent environment in Iraq and Syria. The economic study of the maritime route design for LNG transport are scarce. For this region, the only way to supply their natural gas remains the LNG tanker.

In this paper a model derived in a generic form in this paper could be used by a shipper to calculate the breakeven point between two maritime service ports, where the transit by the Suez Canal is an option. The model is not greedy in data and uses available public information related to the transit tolls through the Suez Canal, the charter rates and the war insurance premium connected to each route. Therefore, this paper overcome the non-availability of public data which represents a significant "barrier to entry" for academic research in the field and offer to the management practitioners a model far from the complexity, easy to understand and to apply. To illustrate this model, we used data associated to a service from Qatar-Turkey to transport LNG by LNG vessel tankers.

The output of the model gives tools to the shipper to negotiate with carrier. After becoming common in the recent years, the slow steaming is not any more respected in practice due to the low price of the vessels bunker and a lack of transparency over its benefits, and limited existing research available to provide resolution. As such, shippers are in favor for a higher steaming in order to reduce transit times and to reduce pipeline inventory.

Specifically, the findings are the Suez Canal route remain a cost efficiency when the difference between the 
distances of the two routes is 3,000 miles or more representing one week travel. Moreover, the optimal speed calculated to reduce the fuel consumption is not respected in practice. Finally, the model gives the opportunity to the shipper to compare any time his breakeven point between the routes options and to compare it with the market charter rate.

In this research, we did not discussed the environment dimension that could be reflected by $\mathrm{CO}_{2}$ carbon tax. If it is the case to be considered, it will privileges more the Suez Canal route. The same thought will be applied if the pipeline inventory cost in considered.

\section{ACKNOWLEDGEMENTS}

A would like to thank the anonymous reviewers for their valuable comments which contributed to improve the paper. Also, Camelia Lakhal by reading the final version has contributed to improve the English quality of the paper. Finally, the financial contribution of Social Sciences and Humanities Research Council, SSHRC and the New Brunswick Innovation Foundation NBIF research grants were very helpful to achieve this research.

\section{REFERENCES}

Agra, A., Christiansen, M., Delgado, A., \& Hvattum, L. M. (2015). A maritime inventory routing problem with stochastic sailing and port times. Computers \& Operations Research, 61, pp. 18-30.

Al-Khayyal, F. and H. Seung-June (2007). Inventory constrained maritime routing and scheduling for multi-commodity liquid bulk, Part I: Applications and model. European Journal of Operational Research 176(1), pp. 106 - 130.

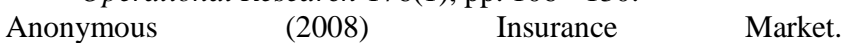
https://www.strausscenter.org/hormuz/insurancemarket.html, acceded on 2017- 02-16.

Bernstein, P., Tuladhar, S. D., \& Yuan, M. (2016). Economics of US natural gas exports: Should regulators limit US LNG exports? Energy Economics, 60, pp. 427-437.

Braden, D. (2016). Lines could save big by routing via Cape of Good Hope. Journal of Commerce 29 Feb 2016.

Bridier, G. (2014). Gaz: l'Europe peut se dégager de l'étau russe. Slate. Paris, France. http://www.slate.fr/story/90769/gazeurope-russie-etau, accessed on 2017- 02-16.

Chandra, S., Srivastava, R. K., \& Agarwal, Y. (2013). Multiproduct maritime inventory routing with optional cargoes: an application to outbound automotive logistics. Journal of Advances in Management Research, 10(2), pp. 206-229.

Christiansen, M., Fagerholt, K., Flatberg, T., Haugen, Ø., Kloster, O., \& Lund, E. H. (2011). Maritime inventory routing with multiple products: A case study from the cement industry. European Journal of Operational Research, 208(1), pp. 8694.

Christiansen, M., Fagerholt, K., Nygreen, B., \& Ronen, D. (2007). Maritime transportation. Handbooks in operations research and management science, 14, pp. 189-284.

Christiansen, M., Fagerholt, K., \& Ronen, D. (2004). Ship routing and scheduling: Status and perspectives. Transportation Science, 38(1), pp. 1-18.

Effendy, S., Khan, M. S., Farooq, S., \& Karimi, I. A. (2017). Dynamic modelling and optimization of an LNG storage tank in a regasification terminal with semi-analytical solutions for N 2-free LNG. Computers \& Chemical Engineering, 99, pp. 40-50.

Engineer, F. G., Furman, K. C., Nemhauser, G. L., Savelsbergh, M. W., \& Song, J. H. (2012). A branch-price-and-cut algorithm for single-product maritime inventory routing. Operations Research, 60(1), pp. 106-122.
EY (2017). New pricing ahead - LNG demand growth._Industries; Oil \& Gas; Global LNG: Retrieved 2017-01-26, 2017, from http://www.ey.com/gl/en/industries/oil---gas/global-lng-new-pricing-ahead---lng-demand-growth, accessed on 2017 02-16.

Faury, O. and P. Cariou (2016). The Northern Sea Route competitiveness for oil tankers. Transportation Research Part A: Policy and Practice 94, pp. 461-469.

Furuichi, M. and N. Otsuka (2015). Proposing a common platform of shipping cost analysis of the Northern Sea Route and the Suez Canal Route. Maritime Economics \& Logistics 17(1), pp. 9-31.

Gold, E. Q. C. (2014). Shipping in Arctic Waters: A Comparison of the Northeast, Northwest and Trans Polar Passages. Journal of Maritime Law and Commerce 45(2), pp 277-279.

Ha, Y.-S. and J. S. Seo (2014). The Northern Sea Routes and Korea's Trade with Europe: Implications for Korea's Shipping Industry. International Journal of e-Navigation and Maritime Economy 1, pp. 73-84.

Hennig, F., Nygreen, B., Furman, K. C., Song, J., \& Kocis, G. R (2011). Crude oil tanker routing and scheduling. INFOR: Information Systems and Operational Research, 49(2), pp. 153-170.

Hewitt, M., Nemhauser, G., Savelsbergh, M., \& Song, J. H. (2013) A branch-and-price guided search approach to maritime inventory routing. Computers \& Operations Research, 40(5), pp. 1410-1419.

Hill, E., LaNore, M., \& Véronneau, S. (2015). Northern sea route: an overview of transportation risks, safety, and security. Journal of Transportation Security, 8(3-4), pp. 69-78.

Ho, J. (2009). The implications of Arctic sea ice decline on shipping. Marine Policy 34(3), pp. 713-715.

ICC (2016). IMB Piracy \& Armed Robbery Map 2016. Commercial Crime Service https://icc-ccs.org/piracy-reportingcentre/live-piracy-map, accessed on 2017- 02-16

ICC (2016). Piracy and Armed Robbery Against Ships, ICC International Bureau. https://icc-ccs.org/piracy-reportingcentre/request-piracy-report, accessed on 2017- 02-16.

Khon, V. C., Mokhov, I. I., Latif, M., Semenov, V. A., \& Park, W. (2010). Perspectives of Northern Sea Route and Northwest Passage in the twenty-first century. Climatic Change, 100(34), pp. 757-768.

Lakhal, S. Y., \& H'Mida, S. (2017). The red-med railway project a serious competitor to the Suez Canal for caro containers? Independent Journal of Management \& Production 8(3).

Lee, S.-W. and J.-M. Song (2014). Economic Possibilities of Shipping though Northern Sea Route1. The Asian Journal of Shipping and Logistics 30(3), pp. 415-430.

Lee, T. and H. J. Kim (2015). Barriers of voyaging on the Northern Sea Route: A perspective from shipping Companies. Marine Policy 62, pp. 264-270.

Lin, D.-Y. and Y.-Y. Tsai (2014). The ship routing and freight assignment problem for daily frequency operation of maritime liner shipping. Transportation Research. Part E, Logistics \& Transportation Review 67, pp. 52 - 70.

Lindstad, H. and G. S. Eskeland (2015). Low carbon maritime transport: How speed, size and slenderness amounts to substantial capital energy substitution. Transportation Research Part D: Transport and Environment 41, pp. 244 256.

Liu, M. and J. Kronbak (2010). The potential economic viability of using the Northern Sea Route (NSR) as an alternative route between Asia and Europe. Journal of Transport Geography 18(3), pp. 434-444.

Marcel, J. H. B. G. (2006). Routing of platforms in a maritime surface surveillance operation. European Journal of Operational Research 170(2), pp. 613-628.

Okumuş, O. (2015) Will Turkey be able to replace Russian gas with Qatari imports? http://www.al- 
monitor.com/pulse/originals/2015/12/turkey-russia-qatarcannot-replace-russian-gas.html\#ixzz443iQhtMu, accessed on 2017-02-16.

Papageorgiou, D. J., Keha, A. B., Nemhauser, G. L., \& Sokol, J. (2014). Two-stage decomposition algorithms for single product maritime inventory routing. INFORMS Journal on Computing, 26(4), pp. 825-847.

Papageorgiou, D. J., Nemhauser, G. L., Sokol, J., Cheon, M. S., \& Keha, A. B. (2014). MIRPLib-A library of maritime inventory routing problem instances: Survey, core model, and benchmark results. European Journal of Operational Research, 235(2), pp. 350-366.

Paris, C. (2014). Greek Shipowners Splash the Cash on LiquefiedNatural-Gas Carriers: Owners Bet That Falling Energy Prices Will Spur Demand for Such Vessels. The Wall Street Journal. New York.

Pierre, C. and F. Olivier (2015). Relevance of the Northern Sea Route (NSR) for bulk shipping. Transportation Research Part A: Policy and Practice 78, pp. 337-346.

Rahman, N. A., Saharuddin, A. H., \& Rasdi, R. (2014). Effect of the Northern Sea Route Opening to the Shipping Activities at Malacca Straits. International Journal of e-Navigation and Maritime Economy, 1, pp. 85-98.

Roche, M. (2009) La piraterie fait exploser les primes d'assurances. Le Monde http://www.lemonde.fr/economie/article/2009/04/16/lapiraterie-fait-exploser-les-primes-dassurances_1181520_3234.html\#c2j9iOiACEXDjwrW.99, accessed on 2017-02-16.

RS-Platou (2015). Low Oil Price effect Effects on Gas Shipping. R. P. Monthly, Rs Platou. http://shipbroker.no/wordpress/wpcontent/uploads/2015-01-Platou-Monthly.pdf, accessed on 2017- 02-16.
Schøyen, H. and S. Bråthen (2011). The Northern Sea Route versus the Suez Canal: cases from bulk shipping. Journal of Transport Geography 19(4).

Seanews (2013) Drewry: Cape route can compensate for Suez slowdown with no loss of speed. http://www.seanews.com.tr/news/108038/Drewry-Caperoute-can-compensate-for-Suez-slowdown-with-no-loss-ofspeed-.html, accessed on 2017- 02-16.

Song, J.-H. and K. C. Furman (2013). A maritime inventory routing problem: Practical approach. Computers \& Operations Research 40(3), pp. 657 - 665.

Stokes, D. and O. Spinks (2015) Collapse in LNG charter rates continues. http://www.timera-energy.com/collapse-in-lngcharter-rates-continues/, Date accessed: March 15, 2016.

Verny, J. and C. Grigentin (2009). Container shipping on the Northern Sea Route. International Journal of Production Economics 122(1), pp. 107-117.

Wallis, K. (2015) LNG shippers brace for wave of consolidation as freight rates sink. http://www.reuters.com/article/lng-freightrates-idUSL3N14438C20151221, acceded on 2017- 02-16.

Wilmsmeier, G. and T. Notteboom (2011). Determinants of liner shippping network configuration: a two-region comparison. GeoJournal 26(3), pp. 213-228.

Zelasney, J., Huppert, D., \& Leschine, T. (2011). The influence of oil price on maritime routing of containerized imports from China. Maritime Economics \& Logistics, 13(3), pp. 298-318.

Zhang, Y., Meng, Q., \& Zhang, L. (2016). Is the Northern Sea Route attractive to shipping companies? Some insights from recent ship traffic data. Marine Policy, 73, pp. 53-60.

Zhao, H., Hu, H., \& Lin, Y. (2016). Study on China-EU container shipping network in the context of Northern Sea Route. Journal of Transport Geography, 53, pp. 50-60.

Salem Y. Lakhal is a Professor at the Faculty of Business Administration, University of Moncton, New Brunswick, Canada. He teaches courses on project management, and supply chain management. He is also the founding Director of the Center for Green Supply Chain. His research interests are maritime transport, the green supply chain applied in the petroleum, pricing, and value-added sharing. He holds a BSc in Electromechanical Engineering, an MSc in Operations Management and a PhD in Operations Management and Decision Sciences. His current researches interests include, resilient supply and maritime transport design. 